\title{
Scholars' Reply to Professor Fried
}

As Solicitor General of the United States, Charles Fried, like any good advocate, was often in the position of attempting to generate broad holdings from relatively narrow and particularistic Supreme Court decisions. This was especially true in affirmative action cases. There, the Department of Justice argued that cautious precedents actually stood for the broad proposition that measures designed to put members of disadvantaged groups on a plane of equality should, for constitutional purposes, be treated the same as measures intended to stigmatize or subordinate them. ${ }^{1}$ The Supreme Court, however, has consistently rejected this reading of its precedents and the broad proposition as well.

In Regents of the University of California v. Bakke, Justice Powell, applying strict scrutiny, cast the tie-breaking vote in favor of the view that the University's and society's interest in diversity justified racial preferences in education. In Fullilove v. Klutznick, ${ }^{3}$ the Court, again applying heightened scrutiny, upheld a racial quota in the construction industry. In Local 28 of the Sheet Metal Workers' International Association v. $E E O C$, ${ }^{4}$ the Court, once more applying strict scrutiny, upheld a courtordered numerical "racial goal" tied to the percentage of nonwhites in the relevant workforce. In United States $v$. Paradise, ${ }^{5}$ again applying strict scrutiny, the Court sustained a promotional quota on all upper ranks so

1. See Brief for the United States, Wygant v. Jackson Bd. of Educ., 476 U.S. 267 (1986) (No. 841340); Brief for the United States, Local 28 of the Sheet Metal Workers Int'l Ass'n v. EEOC, 478 U.S. 421 (1986) (No. 84-1656); Brief for the United States, United States v. Paradise, 480 U.S. 149 (1987) (No. 85-999); see also Brief for the United States, Johnson v. Transportation Agency, 480 U S. 616 (1987) (No. 85-1129); Brief for the United States, Firefighters Local Union No. 1784 v. Stotts, 467 U.S. 561 (1984) (Nos. 82-206, 82-229). Compare the somewhat more cautious Brief for the United States, taking precedent more seriously, in City of Richmond v. J.A. Croson Co., 109 S. C. 706 (1987) (No. 87-998).

This understanding of the Constitution is captured by Fried's suggestion that "the equal protection clause protects all equally." See Fried, Affirmative Action After City of Richmond v. J.A. Croson Co.: A Response to the Scholars' Statement, 99 YALE L.J. 155, 160 (1989). In one sense this is true, but it cannot do the analytic work that Fried thinks it can. Even a cursory glance at the Court's cases reveals that to be protected "equally" does not mean to be treated the same. See, e.g., Williamson v. Lee Optical Co., 348 U.S. 483 (1955); Craig v. Boren, 429 U.S. 190 (1976); see also Strauss, The Myth of Colorblindness, 1986 Sup. CT. REv. 99. As these cases-and indeed the entire structure of equal protection doctrine-reveal, whether one has been protected "equally" depends not on whether one has been treated "the same," but instead on the legitimacy and weight of the reasons for which one has (or has not) been treated differently. It is here that the Court's decisions, including Croson, recognize that affirmative action presents distinctive considerations.

2. 438 U.S. 265 (1978).

3. 448 U.S. 448 (1980). In Fullilove, the plurality said that it need not decide between strict and intermediate scrutiny, because the measure would survive either-an approach reiterated in some of the other cases referred to in the text.

4. 478 U.S. 421 (1986).

5. 480 U.S. 149 (1987). 
long as there were qualified black candidates. Indeed, Paradise instructs us that, upon solid findings of discrimination, principally at the entry level, it is permissible to have a fifty percent racial quota in promotion as a means of eliminating the effects of past discrimination as quickly as possible.

In Wygant v. Jackson Board of Education, ${ }^{6}$ the Court did conclude that a preferential layoff provision was inadequately justified. Even there, however, Justice O'Connor, applying strict scrutiny, emphasized that the "imposition of a requirement that public employers make findings that they have engaged in illegal discrimination before they engage in affirmative action programs would severely undermine public employers' incentive to meet voluntarily their civil rights obligations."

In his response, Professor Fried continues to claim that the Court's complex decisions on affirmative action can be reduced to the relatively simple proposition that race-conscious measures-whatever the context, whoever the governmental actor, and whether the intended beneficiaries are white or members of disadvantaged groups-are impermissible except in the most extraordinary of circumstances. What Solicitor General Fried maintained in briefs before the Supreme Court, about Bakke and Fullilove in Wygant and Sheet Metal Workers; and about Wygant and Sheet Metal Workers in Paradise, Professor Fried now repeats, in these pages, about Croson. ${ }^{8}$

The claim is unpersuasive. As our statement suggests, the law in this area contains complex guidelines and enumerates relevant and irrelevant factors rather than absolute rules. ${ }^{\circ}$ Significantly, in Croson every other member of the Court rejected Justice Scalia's view that affirmative action should be treated the same as discrimination against members of racial minority groups. ${ }^{10}$ A majority of the Justices continue to accept Fullilove, which gives the national government vast power to create affirmative action programs. Justice O'Connor's plurality opinion in Croson reads very much like Justice Powell's opinion in Bakke-and Justice Powell voted to uphold many affirmative action programs. Indeed, it is Justice Powell who first put forth the idea that, in some contexts, forward-looking justifications will be sufficient to support such programs. ${ }^{11}$

6. 476 U.S. 267 (1986).

7. Id. at 290 .

8. See also Brief for the United States, Johnson v. Transportation Agency, 480 U.S. 616 (1987) (No. 85-1129).

9. See Constitutional Scholars' Statement on Affirmative Action After City of Richmond v. J.A. Croson Co., 98 YALE L.J. 1711 (1989) [hereinafter Statement]. Such an approach is unsurprising in this difficult area, which covers a wide range of contexts for which rigid approaches would be illsuited.

10. Justice Kennedy expressed sympathy for Justice Scalia's position, but acknowledged that it was inconsistent with precedent and said he was "not convinced" that the Court "need adopt it at this point." Croson, 109 S. Ct. at 734 (Kennedy, J., concurring in part and concurring in judgment).

11. See also Sullivan, Sins of Discrimination: Last Term's Affirmative Action Cases, 100 HaRv. 
Finally, and most important, the decisive votes in Croson came from Justices who emphasized context and particulars rather than bright-line rules. Justice O'Connor's plurality opinion stresses:

(1) Richmond's use of "an unyielding racial quota" rather than a racial preference system with flexibility, including waiver provisions; ${ }^{\mathbf{1 2}}$

(2) the absence of a "prima facie case of a constitutional or statutory violation by anyone in the Richmond construction industry" ${ }^{13}$

(3) Richmond's undue reliance on statistical evidence too broad or too vague to be informative about discrimination in that industry, ${ }^{14}$ and

(4) Richmond's failure to consider alternative remedies ${ }^{15}$ or individualized forms of relief. ${ }^{16}$

Indeed, the plurality said that "a narrowly tailored racial preference might be necessary to break down patterns of deliberate exclusion" on the basis of a "significant statistical disparity between the number of qualified minority contractors willing and able to perform a particular service and the number of such contractors actually engaged by the locality or the locality's prime contractors. . ."17 It is in light of these considerations-stressing the highly distinctive context of the Richmond plan and leaving room for race-conscious remedies in other contexts-that our statement was written.

Fried suggests that Croson signals a substantial change in the law of affirmative action because in that case a Supreme Court majority adopted, for the first time, a test of strict scrutiny for all racial classifications. But this overstates the implications of the case. As noted above, Supreme Court majorities, or Justices whose votes were crucial to majorities, have applied strict scrutiny, and upheld affirmative action programs, on many occasions. Since what amounts to strict scrutiny has been applied in the key opinions in all of the relevant cases, the use of that standard is hardly surprising and, by itself, cannot plausibly be said to signal a major change of direction. Strict scrutiny is as strict scrutiny does. Discrimination against members of minority groups must overcome what is virtually a

\section{REv. 78 (1986).}

Croson, following Justice Powell's lead in Wygant, rejects the "role model" theory of affirmative action; but it does not deal with the general question of forward-looking justifications. Justice Powell, for one, rejected "role model" theories without rejecting diversity as a justification in education; see also Justice Stevens' endorsement of forward-looking justifications in both Croson and Johnson.

12. Croson, 109 S. Ct. at 724.

13. Id. at 724 (emphasis in original).

14. Id. at $724-27$.

15. Id. at 728 .

16. Id. at $728-29$.

17. Id. at 729. Despite Professor Fried's discussion of "crystal balls," Fried, supra note 1, at 158 $\mathrm{n.26}$, this language cannot be wished away simply because of the Court's later holding in Wards Cove Packing Co. v. Atonio, 109 S. Ct. 2115 (1989)-a case presenting an altogether different issue-that statistical disparity alone does not shift to the defendant the burden of justifying its employment practices under Title VII. 
conclusive presumption of unconstitutionality. ${ }^{18}$ Affirmative action programs, even under strict scrutiny, need not do so.

Fried's disagreements with our statement primarily involve matters of degree and emphasis. But if we read Fried correctly, he seems to think that Justice O'Connor's plurality opinion in Croson implicitly overrules $B a k k e,{ }^{18}$ represents a retreat from her position in Wygant, ${ }^{20}$ and may well adopt the position of the dissents in Sheet Metal Workers and Paradise (though he is not clear on this point).

In short, Fried appears to recast Croson as adopting precisely the views of the Office of the Solicitor General on affirmative action-notwithstanding the fact that those same views have been frequently, and emphatically, rejected by the Supreme Court during the past four terms. For a Court committed to judicial restraint, this would be exceptionally surprising.

Affirmative action programs have been approved, time and again, by the American people acting through the democratic branches of government-and at the national, state, and local level. In at least some forms, they have been approved by the Supreme Court. They are now firmly embedded in American practice and American law, and they span an enormous range. To cite just two examples: (1) Executive Order No. 11,246-involving government contracts, written by President Johnson and enforced by Presidents Nixon, Ford, Carter, Reagan and Bush-contains one of the most important affirmative action programs; ${ }^{21}$ (2) thousands of public educational institutions, ${ }^{22}$ attempting to provide a more diverse group of students and faculty, have, of their own volition, followed Justice Powell's direction not to adopt quotas but instead to consider minority status as one among many relevant factors.

To think that Croson imposes a national constitutional barrier-to be enforced by federal judges-to such programs would be to read it as a startling departure from the Court's cautious approach to the difficult problem of remedying the long legacy of discrimination against members of minority groups. We prefer to see Croson as the pragmatic and particularistic opinion that it is.

18. The only exception is Korematsu v. United States, 323 U.S. 214 (1944), which of course involved the highly unusual circumstance of a military exclusion order.

19. Fried, supra note 1, at 158-59.

20. Id. at 160 .

21. Exec. Order 11,246, (1965), 3 C.F.R. 339, (1964-65) reprinted in 42 U.S.C. $\$ 2000$ e app. at 28-31 (1982). On October 13, 1967, the order was expanded to include gender. See Exec. Order 11,375 , (1967), 3 C.F.R. 320 reprinted in U.S.C. $\S 2000$ e app. at 28-31 (1982).

22. Fried notes, correctly, that Croson does not directly bear on the conduct of private actors. But if one took the view that Fried expressed as Solicitor General, see Briefs for the United States in Johnson and Paradise, supra note 1, the Civil Rights Acts would be read as a bar to race-conscious private behavior. That is a reading and a view also rejected-with emphasis-by the Court. See Johnson v. Transportation Agency, 480 U.S. 616 (1987); United States v. Paradise, 480 U.S. 149 (1987). 
Judith C. Areen ${ }^{23}$

Dean and Professor of Law

Georgetown University

Law Center

Barbara A. Black

Dean and George Welwood

Murray Professor of

Legal History

Columbia University School of Law

Philip C. Bobbitt

Cooper K. Ragan Regents

Professor of Law

University of Texas

School of Law

Lee C. Bollinger

Dean and Professor of Law

University of Michigan Law School

\section{Paul Brest}

Dean and Richard E. Lang

Professor of Law

Stanford Law School

Guido Calabresi

Dean and Sterling Professor

of Law

Yale Law School

Denise S. Carty-Bennia

Professor of Law

Northeastern Law School

Jesse H. Choper

Dean and Professor of Law

University of California at

Berkeley School of Law
Peggy C. Davis

Professor of Law

New York University

School of Law

Drew S. Days III

Professor of Law

Yale Law School

Walter F. Dellinger III

Professor of Law

Duke University School of Law

Norman Dorsen

Frederick I. \&

Grace A. Stokes

Professor of Law

New York University

School of Law

Christopher F. Edley, Jr.

Professor of Law

Harvard Law School

Yale Kamisar

Henry K. Ransom

Professor of Law

University of Michigan

Law School

Kenneth L. Karst

Professor of Law

UCLA School of Law

Herma Hill Kay

Professor of Law

University of California at

Berkeley School of Law

Patricia A. King

Professor of Law

Georgetown University

Law Center

23. Deans and professors are signing on their own behalf and not as representatives of their schools. 
Gerald P. Lopez

Kenneth \& Harle Professor of

Public Interest Law

Stanford Law School

Burke Marshall

Nicholas deB. Katzenbach

Professor of Law

Yale Law School

Frank I. Michelman

Professor of Law

Harvard Law School

Eleanor Holmes Norton

Professor of Law

Georgetown University

Law Center

Robert M. O'Neil

President, University of

Virginia and George

M. Kaufman Professor

of Law University of

Virginia School of Law

Susan W. Prager

Dean and Professor of Law

UCLA School of Law

Dean Rusk

Samuel H. Sibley Professor of

International Law

University of Georgia

School of Law
John E. Sexton

Dean and Professor of Law

New York University

School of Law

Geoffrey R. Stone

Dean and Harry Kalven, Jr.

Professor of Law

University of Chicago Law

School

Cass R. Sunstein

Karl N. Llewellyn Professor

of Jurisprudence

University of Chicago Law

School and Department

of Political Science

University of Chicago

Laurence $\mathrm{H}$. Tribe

Ralph S. Tyler, Jr. Professor

of Constitutional Law

Harvard Law School

James Vorenberg

Roscoe Pound Professor of Law

Harvard Law School 